\title{
Education and Employment Outcomes in Ghana through the Lens of the Capability Approach
}

\author{
Adu Owusu Sarkodie ', Samuel Agyei-Mensah ${ }^{2}$, John K. Anarfi ${ }^{3}$ and \\ Thomas Antwi Bosiakoh ${ }^{4}$ \\ ${ }^{1}$ Department of Economics, University of Ghana, Legon \\ ${ }^{2}$ Department of Geography and Resource Development, University of Ghana, Legon \\ ${ }^{3}$ Regional Institute of Population Studies, University of Ghana, Legon \\ ${ }^{4}$ Department of Sociology, University of Ghana, Legon \\ brosark@yahoo.com
}

\section{Abstract}

Existing literature on education and employment confirms that in Ghana educational qualification largely influences the type of work. Through the lens of the Capability Approach, which sees human development in terms of the expansion of freedoms and opportunities, this paper identifies, for a cross-section of Ghanaians, the array of employment opportunities between and within education endowments. "Between endowments" refers to differentials in opportunities for individuals with different levels of educational qualifications, while "within endowments" considers the differentials for individuals with the same level of education. The source of data is the 2005/06 Ghana Living Standard Survey (GLSS5). Results show that education is not enough to erase inequalities. Multinomial regression analysis demonstrates that functionings differ according to the individual's context, household and personal conversion factors. This is explained by inequalities in the requirements for a particular job (between educational endowments) and by job accessibility due to personal characteristics (within educational endowments).

Keywords: education, employment, Capabilities, conversion factors, Ghana.

\section{Résumé}

\section{Scolarisation et emploi au Ghana à travers la lunette de l'approche des Capabilités}

La littérature confirme que, au Ghana, la qualification scolaire influence considérablement le type d'emploi occupé. A travers la lunette des Capabilités, qui considère le développement humain en termes d'expansion des libertés, cet article analyse l'éventail d'opportunités professionnelles entre et à l'intérieur des groupes de dotation scolaire. L'analyse entre groupes examine les différences selon le niveau de scolarisation, alors que l'analyse intra-groupe se réfere aux différences entre individus de même niveau. Nous utilisons les données de l'enquête 2005/06 sur les conditions de vie au Ghana (GLSS5). Les résultats montrent que la scolarisation ne suffit pas pour effacer les inégalités. Des analyses de régressions multinomiales montrent que les réalisations professionnelles different selon le contexte et les caractéristiques familiales et individuelles. Ceci est expliqué par les inégalités d'exigences pour les différents types d'emploi (différences entre dotations scolaires) et d'accessibilité des emplois selon les caractéristiques personnelles (différences à l'intérieur des groupes de dotation scolaire).

Mots-clés: scolarisation, emploi, Capabilités, facteurs de conversion, Ghana. 


\section{Introduction}

Nations have been ranked as being more or less developed; policies often are chosen on the basis of their expected contribution towards development; development programs are assessed in terms of their impact on development; and economists measure and advise on what is instrumental to development. In fact, theories have and continue to influence the social issues that are seen (or not seen), the policies that are chosen (or not chosen), the indexes that are used (or not used) to assess and rank countries, regions or single program they more or less directly contribute to shaping the world we live in. What then is the common measure of human development? There have been many approaches to human development. Some of these approaches include the Welfarists Approach (income and consumption), Utilitarian Approach (happiness/good/pleasure), Basic needs Approach (food, shelter, sanitation, water) and the Classical Economics Approach (GDP/per capita income) to human development. New approaches to human development have evolved through the globalization process. Over the last decade, Amartya Sen's Capability Approach (CA) has emerged as the leading alternative to standard framework for understanding poverty, inequality, and human development in general. According to the CA, development is seen as "a process of expansion of real freedoms enjoyed by individuals in order to lead the kind of lives they have reason to value "(Sen 1999; 3-10). The Capability Approach provides the intellectual foundation for human development. The core characteristic of the approach is its focus on what people can effectively be or do as against their actual beings and doings. A focus on people's Capabilities in the choice of development makes a profound theoretical difference, and leads to quite different policies compared to neo-liberalism and utilitarian policy prescriptions.

As young individuals grow into adulthood, there are many risks and opportunities associated with this transition in life. It is the hope of these individuals to achieve a meaningful employment status that enables them to play their role in society. One tool with which to achieve this meaningful employment status and eventually enable individuals to play their role in society is education. However, as with other life enhancing social services, educational access in Ghana and elsewhere in other developing economies is unequal to different categories of people. More significantly, there is the need to explore the role of education (different segments of the Ghanaian population with different educational attainments) in attaining employment or, in other words, better understand the education/employment nexus.

\section{Current State of Knowledge}

The school enrolment indicators in the 2009/2010 academic year in Ghana showed mixed progress. Preschool and primary enrolments are nearly universal, while it is still far from being the case at higher levels. Enrolments at pre-school level rose from $93 \%$ in 2008/2009 to a high of 97.3 percent in 2009/2010 and Gross Enrolment Ratios at primary level maintained the 2008/09 level of about 95 percent. Progress with net enrolments at the primary level however, showed a slight dip in the 2009/2010 academic year. At the Junior High School (JHS) level, gross and net enrolments remained at 79.5 percent and 48 percent respectively.

To ensure achievement of Universal Basic Completion by 2015 , enrolments and retention need to improve, while dropouts or repetitions need to be reduced. Government of Ghana has instituted a number of measures to ensure increasing enrolments, retention and completion as well as good quality education. These include timely disbursement of the capitation grant, classroom construction to expand access, provision of free school uniforms in deprived areas, and provision of free exercise books. In addition, schools under 
trees are being phased out to ensure a more conducive atmosphere for learning.

The Gender Parity Index (GPI) at the primary level remained at 0.96 in the 2009/10 academic year. GPI at the JHS level has also remained at 0.92 . Gender disparities have received increasing focus over the past decade, especially with the introduction of the capitation grant scheme, which has contributed significantly to female enrolment.

The link between education and employment has been considered by economists through the return of education to earnings. Evidence suggests that overall returns to an extra year of formal education is low in Africa (3.5 per cent), and for women about half of men's (Uwaifo Oyelere, 2005). In Ghana, returns from primary schooling became almost nil toward the end of the 1980s, as a consequence of the expansion of primary education (Lavy, 1992). Though returns from secondary level education were much higher, the cost of staying in school after primary level was often too high for many Ghanaian households to afford (Lavy, 1992, Mancini, 2009). This expectedly had a shrink back effect on primary school enrolment with drop-out rates increasing because as argued by Sunal et al (2003) in the case of Nigeria, sending children to primary school was viewed by parents as worthwhile only if the child had the potential to move on to a higher level, possibly to the secondary school or beyond.

Teal (200I) also provides some interesting details on the relationship between education and employment, and education-poverty nexus situation in Ghana in the 1990s. Using four waves of GLSS data from 1988 to 1999, Teal estimates returns to education not only in the wage employment segment of the Ghanaian labour market but also in two other major occupations namely agriculture (employing more than $60 \%$ of the labour force in 1998-99) and self-employment. Teal argues that there is a clear hierarchy of employment usability for education (see also Kingdon, and Söderbom, 2007: 8). While the most educated Ghanaian workers are in the public sector with about 12.4 years of education, those in the private wage sector have only 9.3 years of education. For workers in the non-agricultural selfemployment category, the average number of years they had spent in school was 6 years and for farmers 3.6 years. There is a similar conclusion in all other years (Teal, 200I) (See Table I).

Table I: Trends in education by Type of Work

\begin{tabular}{|c|c|c|c|c|}
\hline & $1987 / 88$ & $1988 / 89$ & $1991 / 92$ & $1998 / 99$ \\
\hline \multicolumn{5}{|c|}{ Work categories \& years of education } \\
\hline Public Wage Job & 490 & 537 & 560 & 474 \\
\hline Years of education & 9.4 & 10.0 & 10.2 & 12.4 \\
\hline Private Wage Job & 353 & 401 & 336 & 404 \\
\hline Years of education & 7.0 & 7.5 & 8.4 & 9.3 \\
\hline Non-Agricultural Self Employment & 1,004 & 1,309 & $\mathrm{I}, 350$ & 1,664 \\
\hline Years of education & 4.4 & 4.8 & 5.0 & 6.0 \\
\hline Farmer & 1,804 & 2,066 & 2,353 & 2,855 \\
\hline Years of education & 2.8 & 3.1 & 3.3 & 3.6 \\
\hline All workers & 3,651 & 4,313 & 4,599 & 5,397 \\
\hline Years of education & 4.5 & 4.9 & 5.0 & 5.7 \\
\hline \multicolumn{5}{|c|}{ Highest Educational Levels Reached (\%) } \\
\hline No Education & 50.8 & 45.5 & 45.6 & 44.5 \\
\hline Primary or less & 16.8 & 20.2 & 17.9 & 12.0 \\
\hline Middle School Completed & 27.0 & 28.4 & 29.8 & 33.0 \\
\hline Secondary School Completed & 2.5 & 2.9 & 3.8 & 5.2 \\
\hline Some Post secondary & 2.9 & 3.0 & 2.8 & 5.3 \\
\hline
\end{tabular}

Source: GSS Surveys (Teal, 200 I p.20). 
Kingdon and Söderbom (2007) also add some important dimensions to the education/employment discourse on Ghana. First, they examined the role of education in facilitating entry into lucrative occupations, secondly, the role played by cognitive skills in labour market success, (in terms of occupational outcome and earnings), and thirdly whether education mollifies economic inequality or aggravates it. In addition, they estimated returns to education by age group to find out whether the Ghanaian labour market rewards education differently for younger and older workers, and lastly, estimate simple return to technical and vocational education and training (TVET). While recognizing a clear hierarchy in occupational types with respect to education, skills, and earnings, Kingdon, and Söderbom (2007) argue that, wage employment is at the top of all work categories with the most well paid, best educated and the most literate and numerate workers. This is followed by self-employment with lower earnings, education, and cognitive skills, before agriculture, which is last in all these three indicators. In relation to how education facilitates entry into lucrative occupations in Ghana, they report instrumental role of education in promoting a person's entry into the lucrative occupations and in raising earnings. The study suggests that education increases earnings indirectly by helping individuals to gain entry into the high paying occupations, but has low direct effects on earnings for the general population because returns to education in the two largest employed workforces - self-employment and agriculture - are very low.

How much do we know, and we can account for gender-specific dimension of education-employment relationships in Ghana? Alternatively, how do women's education patterns interact with their labour force participation in Ghana? In exploring this, Sackey (2005) made use of data from 1998/99 Ghana Living Standards Survey (i.e., GLSS4) and supplemented it with the GLSS3 for comparative purpose and observed that, women's schooling levels tend to interact with employment sector choices in a distinct manner. He observes that, for women with no schooling, the hope of finding themselves employed in the formal wage sector seems bleak, with an average of only about 5\% managing to do so. For these women without education, close to $65 \%$ of them are in the selfemployment category, and $30 \%$ in the unpaid family labour group. When women attain primary education, the prospect of formal sector employment becomes a little better. Sackey argues that, on average, $10 \%, 71 \%$ and $19 \%$ of these women find themselves in the formal wage employment, self-employment, and unpaid family sectors, respectively. The situation improves further when women attain some post-primary schooling ( ibid, p.19). Sackey also compared the marginal impacts of women's education levels and those of their husbands on women labour force participation for 1991 and 1998 and found out that, for both years, women's schooling exerted a positive impact on participation (except a negative impact of primary schooling for urban women in 1991).

Against the background of studies seeking to explore the relationship between education and employment in Ghana, the significance of the present study is in its grounding of the argument/debate in the Capability Approach. In doing this, we seek to identify the set of employment opportunities available to individuals of same/similar educational attainments and what make them achieve a secured job as the kind of lives they have reason to lead.

\section{Analytical Strategy}

The main thrust of the paper is to estimate the differentials in array of opportunities to achieve a valued job, between and within educational endowments. Between endowments identifies the differentials in the opportunities to achieve between the four levels of educational qualification. Within 
endowments estimates the differentials in opportunities for context, household and individual conversion factors, given that they have the same educational background. The dependent variables are dichotomized, and the effects of the explanatory variables expressed in relative terms. As it is conventional in many studies using Capability Approach, multinomial logistic regression is preferred to any other method. This model enables us to identify the effect of the explanatory variables on the response probability of occurrence of the dependent variable (Greene, 2003). Because the dependent variables are dichotomized, the odd ratio will be reported for the discussion of the analysis. The null hypothesis will be tested at $1 \%$ in order to examine the statistical significance of each explanatory variable. The population at risk is all house members aged between 21 and 40, who have done some work in the 12 months before the interview date. Those who are still in school are exempted.

The data for the study is derived from the Ghana Living Standards Survey-Round Five (GLSS 5). The fifth round of the GLSS was conducted by the Ghana Statistical Service from $4^{\text {th }}$ September 2005 to 3rd September 2006. A nationally representative sample of 8,687 households in 580 enumeration areas, containing 37,128 households members were covered in GLSS5. For the purpose of the study, education is treated as not an end but one of the means to achieve a certain type of employment.

The research questions asked are:

What accounts for the differentials in the opportunities for individuals with:

I. Different educational qualifications?

2. The same educational qualifications, given the Context, Household, and Individual conversion factors?

\section{Variable Mapping}

The first step identified the factors to be considered as functioning, endowments, conversion factors, and capabilities. The Capability Approach identifies what a person is actually able to do or to be; living is a set of interrelated functionings and capabilities (constitutive elements of well-being). A person's Capability to achieve functionings that he or she has reason to value provides a general approach to the evaluation of social arrangements and this yields a particular way of viewing the assessment of equality and inequality.

\section{Functionings and Capabilities}

As recalled in paper I of this volume, functionings refer to achieved beings or doings, while capabilities represent the "freedom to enjoy various functionings [...]; various combination of beings and doings a person can achieve".

Capabilities are the real freedoms to aspire to a certain job. The Capability set is the array of opportunities available to people with some specific endowments or conversion factors. For the purpose of this paper, the capability set is the accessibility of the desired job such as considered through the ability to be gainfully employed. Social networking, discrimination at the work place, success in job interviews and aptitude test are described as constraints to reach the type of work one desires to achieve, notwithstanding the individuals personal preference. These dimensions are not measured here directly but will be introduced in the discussion of the differentials in achievements.

Functionings are described here by the participation in valued productive activities. We rank the types of work according to degree of stable and higher income (from low to higher), such as aggregated in four groups, starting from subsistence agric (32\%), to commercial agric (27\%), non-agric self employment (26\%), and paid work (I5\%). 


\section{Endowments}

We consider education as an endowment, an important basic issue/need to gain employment, categorized as follows (those still in school were exempted) :

○ No education (48\%), i.e. never been to school.

○ Primary (13\%): attended primary school, including those who, for one reason or another, could not attain primary qualifications. The main point is that even a one-year stay in a primary classroom is better than no school at all.

- Middle/JHS (27\%): those who attended Junior High school/JSS/Middle, thus, from JI/BS7 to J3/BS9.

○ SHS+ (I2\%): all educational qualifications higher than JHS/Middle, thus, from SHS/ Vocational/ Technical/ Commercial to the tertiary level.

A cross tabulation between age and education level indicates that the school going age in Ghana is seven years. Thus, by seven years the child should be in primary I. The age range within which one is expected to finish primary education is between seven and thirteen years, rarely after fifteen. By the age of fourteen, one may start the Middle/J.H.S. and is expected to finish by sixteen years. Secondary school education starts at the age of 16 and ends at 20 years, rarely after 26 years.

A further cross tabulation between age and employment shows that the age at which the individual starts work is 20 years. To this effect, the age of the population at risk considered in the present analysis is from 20 years to 40 years because of the clause of transition into adulthood. This is consistent with the labour law of Ghana, which indicates that 15 years and above is the correct age for labour.

\section{Conversion factors}

Conversion factors refer to characteristics that enable one person to valorize more or less his/her endowments to achieve the functionings. In other words, the hypothesis is that conversion factors are mitigating the effect of the education endowment: given the same level of endowments (education), individuals have different abilities to achieve their functionings

In this paper, the conversion factors are categorized into context conversion factors, household, and individual ones. Three context factors are considered: ethnicity, religion and location. The hypothesis is that they provide environments with a varying degree of anchor in traditional values and contact with modernity and technology. The characteristics of the household are measured by the type of dwelling and the use of ICT'. Type of dwellings distinguishes very poor housing (tents and huts) from self-contained (which houses only the nuclear family) and compound house (which also includes other rooms in any form for the members of the extended family). It has been observed that access to ICT is not enough to modify behaviour, it is the use that counts. It is also true that ICT use could be not only a predictor but also an outcome of the activity depending on the type of work one does. Three items make up the use of ICT: fixed line or mobile phones, internet, and personal computers. Individual traits describe the position in the life course (age and marital status) and gender issues (sex). Married people include all those who have 'tasted' marriage before, whether still married, divorced, separated, or widowed.

All the variables discussed above for the variable mapping are represented diagrammatically on Figure I below. 
Figure I: The Capability Approach Model

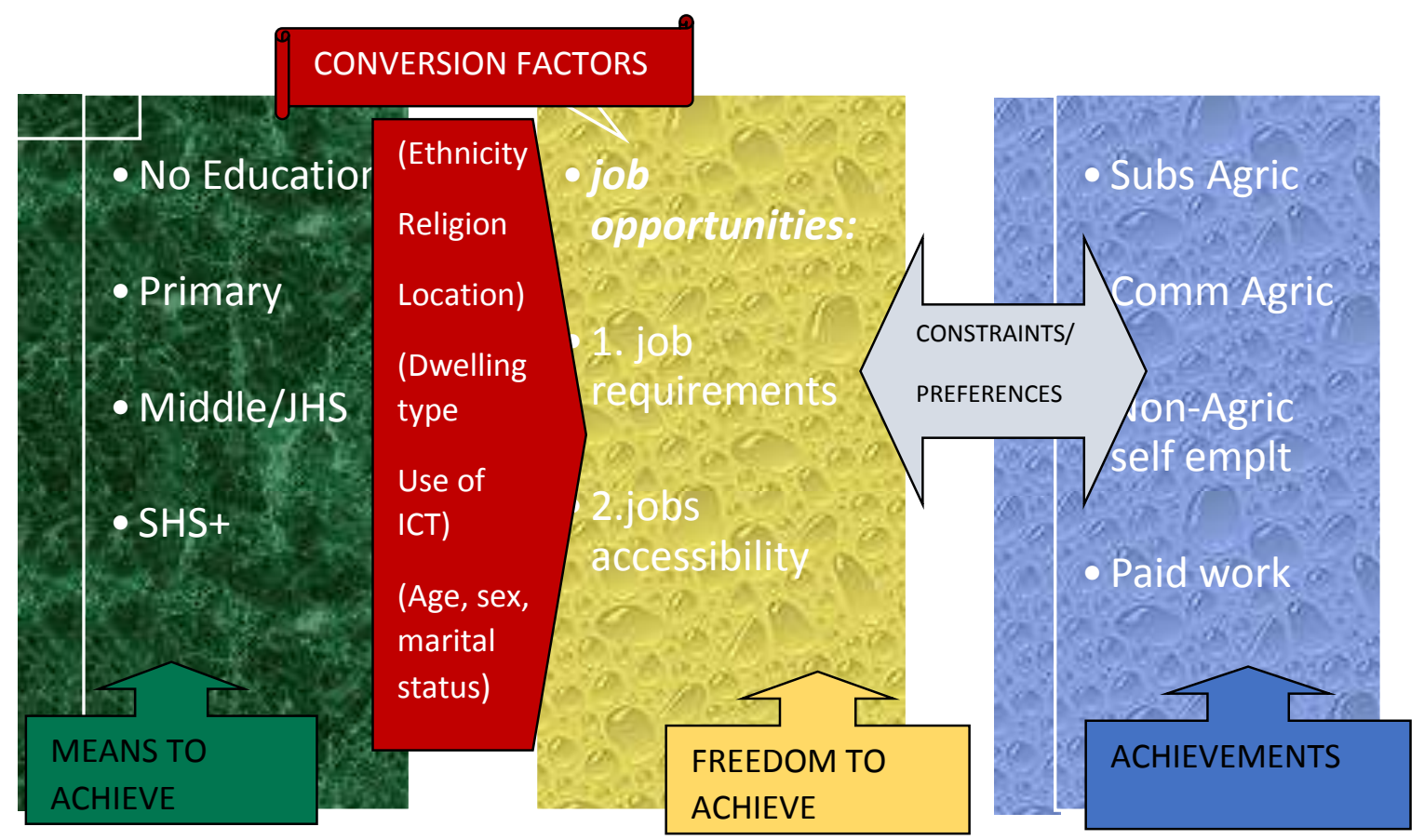

\section{Results}

\section{Differential between educational endowments}

Between endowments analysis is done using a cross tabulation between the levels of educational qualification and the type of work (Table 2). As expected, those with lower education are over represented in the agriculture sector while higher schooling is associated with non-agric activities. More than half of those with SHS+ education end up in paid work.

Yet there is not a straightforward simple association between the level of education and the four groups of activities. This is even more when considering gender specificities. There are gender differences both in the levels of schooling and the type of activities across levels. Women are over represented among those who have never been to school. At all levels of education, except SHS+, they are more often than men, in subsistence agric, and, whatever their level of education, in non-agric self-employment, while men with no or only some schooling are rather to be found in commercial agric and those with middle or high schooling in paid work. 
Table 2. A cross tabulation between Education and Work, by sex.

\begin{tabular}{|c|c|c|c|c|c|c|}
\hline \multirow[b]{2}{*}{ WORK SECTOR } & \multirow[b]{2}{*}{ SEX } & \multicolumn{4}{|c|}{ EDUCATION } & \multirow{2}{*}{$\begin{array}{l}\text { Sample size } \\
\text { (Both sexes) }\end{array}$} \\
\hline & & $\begin{array}{l}\text { NO EDU- } \\
\text { CATION }\end{array}$ & $\begin{array}{l}\text { PRIMA } \\
\text { RY }\end{array}$ & $\begin{array}{l}\text { MIDDLE/ } \\
\text { JHS }\end{array}$ & SHS+ & \\
\hline SUBSISTENCE & $M$ & $39.7 \%$ & $22.2 \%$ & $10.8 \%$ & $9.2 \%$ & $\mathrm{I}, 585$ \\
\hline AGRIC & $\mathrm{F}$ & $48.2 \%$ & $28.6 \%$ & $18.0 \%$ & $9.1 \%$ & 2659 \\
\hline COMMERCIAL & M & $46.3 \%$ & $48.1 \%$ & $38.2 \%$ & $11.5 \%$ & 2,726 \\
\hline AGRIC & $F$ & $24.9 \%$ & $23.2 \%$ & $16.6 \%$ & $1.9 \%$ & 1607 \\
\hline NON-AGRIC SELF & M & $8.5 \%$ & $15.3 \%$ & $23.0 \%$ & $20.1 \%$ & $\mathrm{I}, \mathrm{I} 77$ \\
\hline EMPLOYMENT & $\mathrm{F}$ & $25.0 \%$ & $43.6 \%$ & $57.2 \%$ & $38.4 \%$ & 2888 \\
\hline \multirow[t]{2}{*}{ PAID WORK } & M & $5.5 \%$ & $14.4 \%$ & $28.1 \%$ & $59.2 \%$ & 1667 \\
\hline & $\mathrm{F}$ & $1.8 \%$ & $4.5 \%$ & $8.2 \%$ & $50.7 \%$ & 588 \\
\hline \multirow{2}{*}{$\begin{array}{l}\text { Sample size (both } \\
\text { sexes) }\end{array}$} & & 2508 & 942 & 2573 & 1132 & 7,155 \\
\hline & & 3923 & 1235 & 2000 & 584 & 7,742 \\
\hline
\end{tabular}

Source: GSS (2005/2006); Authors' Computation

NOTES: The bold texts indicate where females' percentages are higher than that of males.

The conclusion is that all the four levels of education offer different job opportunities in the four types of works, but very few persons with a high level of education are working in the agriculture sector. Moreover, men without schooling are rarely found outside agriculture, while non-educated women are also engaged in non-agric self-employment.

The distribution of the conversion factors by types of work and by education levels (cross-tabulations not shown here) indicates that a series of factors are associated both to non agric activities and a higher level of education. Both those in non agric activities (paid work and self-employed) and those with the highest level of education are overrepresented among urban people, those living in nuclear household (self-contained dwelling), and those using ICT. Akan and Christian are also to be mainly found in non agric activities and in the middle or high education levels. Akans are over-represented among the two higher levels, the same is true for Christians. In turn, those who have never been to school are mostly Mole-Dagbani and subsistence agric is more frequent among Mole-Dagbani and people living in tents or huts.
Cohorts have little effect, except that the older ones (36-40) are much less found among the most educated and are over represented in commercial agric, such is the case of married people, who are also to be found in selfemployed. Although single persons are largely over represented in the highest level of education, they are mainly found in the two extreme types of work (subsistence agric and paid work). The gender disparity in schooling is illustrated by a domination of males in higher levels of education compared with women.

\section{Differentials within educational endowments}

\section{The respective effects of different types of conversion factors}

We introduce the different types of conversion factors in blocks into the regression analysis. The purpose is to investigate their correlations such as shown in changes in effects of community conversion factors when introducing subsequent blocks of household and individual characteristics. In other terms, we test whether community traits have proper effects or whether they are the consequences of differences in household characteristics and, 
in turn, in which measure the latter's effect is due to individual differences.

For example the probability of having a paid work among individuals with the highest educational level (SHS+) shows complex correlation between ethnic groups and living context. The advantage of being a Ga-Adangbe, compared with the Akan, disappears when location is considered, and reappears when introducing household characteristics. What it means is that their crude advantage resulted from the fact that they are more often in urban area (known to have more access to paid job), but less in better off households as regards dwelling and access to ICT (also known to be positively associated with paid job). Compared with Akans, Mole Dagbanis are more likely to do paid work when we consider where they live, their type of dwelling and their use of ICT, but their advantage disappears when controlling for their age structure and marital status. In conclusion, being a Ga-Adangbe implies a net advantage over the Akan, whereas it is not the case as for the Mole-Dagbani.

Another observation is that the disadvantage in access to paid work of the youngest age group is declining when introducing marital status. In turn, the disadvantage of being Muslim, living in rural area and not using ICT, and advantage in this regard when living in a self-contained dwelling, being single and male are always significant: they have proper effect independently from other characteristics.

\section{Predictors of job achievement (proper effects of the series of conversion factors)}

This section focuses on the regression results on the belonging to each type of works compared to all others, given each level of education as the endowment (final models with all blocks of conversion factors). This means that we consider the within endowment analysis of differentials in job opportunities, given the conversion factors. The multinomial logit model is well fitted with Pseudo $R^{2}$ of $0.3 \mathrm{I}$, which is a good fit for maximum likelihood estimation. The likelihood ratio test for the model indicates that the independent variables are jointly significant at the $1 \%$ level and the model is well fitted.

For all levels of education, conversion factors influence significantly the job achievement (see Tables 3 and 4). In other words, the education level is not erasing inequalities due to the characteristics considered.

○ Ethnicity has proper effects in all education groups, but the variability is less among the most educated persons in which only Ga-Adangbe and Mole-Dagbani differ from Akan. Compared with Akans, Ga-Adangbes are more likely to engage in non-agric self-employment and paid work when with the highest education; but not in any of the two forms of agric, no matter the level of education. At all levels, except the highest, Ewes are not likely to do subsistence agric, but are rather involved in self-employed jobs while with lower education, and to commercial agric with a middle level. Among those with the highest level, Ewe do not distinguish themselves from Akans. Mole-Dagbanis are more likely to engage in agriculture, subsistence at lower levels of education, but commercial at SHS+. However, no matter the level of education, their opportunities are limited for paid work. Those from other ethnic groups will do subsistence agric only at lower levels of education, but are not likely to engage in commercial agric.

○ Religion: Religion appears to have more influence at extreme education levels. At the lowest and highest levels, Muslims, compared with Christians, are more likely to be self-employed, but less in subsistence agric and less in paid work. Traditionalists have the least opportunities in wage paid works when lacking education, and in commercial agric when having a middle level; they are those most frequently in subsistence agric with higher educational level. 
○ Location: As expected, those who live in rural areas are more prone to work in agriculture and have limited opportunities to be in paid work and non-agric selfemployment, as compared with urban areas. Thus education is not enough to erase disadvantages of rural settings.

- Dwelling type: Dwelling types are associated with the type of work but in a complex way. Our analysis shows that, the categories considered do not correlate with economic activities. At all levels of education, those who live in self-contained houses, i.e. nuclear families mainly, are less likely to work in commercial agric and more likely to have a paid job compared with compound house dwellers. They are however those most involved in subsistence agric when they have no education. Those who live in tents and huts are rather found in commercial agric and non-agric self-employment, but less in subsistence agric, what may express the fact that they lack land property.

- Use of ICT: Whatever their level of education, those who do not use ICT are much more likely to be working in agriculture and, at all levels, usage is highest among self-employed and, when best educated, among those in paid work.
- Age: The younger age group (21-25 compared with ages 26-30) appears to have limited opportunities in commercial agric and paid work. A higher level of education seems to give them lessopportunities than older persons, as shown by the fact that they are those with long education found most often in subsistence agriculture and the least in paid work. At middle education, people aged 3I-35 will do more commercial agric and less non-agric self-employment than those 26-30. The oldest age group (36-40 years) is more likely to do commercial agric and non-agric self-employment, and less subsistence agric.

- Marital status: Compared with married people, those who are single always engage more in subsistence agric at low/middle education, but when they have the highest level of education, they shift to paid works. Not married people are not likely to do commercial agric work no matter their educational level.

- Gender: At all levels of education, and after controlling for all other conversion factos, males are more likely to do commercial agric and paid work, compared with females who in turn are mostly found in subsistence agric or nonagric self-employment. 
- Table 3: Factors influencing employment security of persons from lower levels of education: no education and primary.

\begin{tabular}{|c|c|c|c|c|c|c|c|c|c|}
\hline \multirow[b]{2}{*}{ REGRESSOR } & & \multicolumn{4}{|c|}{ NO EDUCATION } & \multicolumn{4}{|l|}{ PRIMARY } \\
\hline & & $\begin{array}{l}\text { SUBSISTENCE } \\
\text { AGRIC }\end{array}$ & $\begin{array}{l}\text { COMMERCIAL } \\
\text { AGRIC }\end{array}$ & $\begin{array}{l}\text { SELF } \\
\text { EMPLOYMENT }\end{array}$ & $\begin{array}{l}\text { PAID } \\
\text { WORK }\end{array}$ & $\begin{array}{l}\text { SUBSISTENCE } \\
\text { AGRIC }\end{array}$ & $\begin{array}{l}\text { COMMERCIAL } \\
\text { AGRIC }\end{array}$ & $\begin{array}{l}\text { SELF } \\
\text { EMPLOYMENT }\end{array}$ & PAID WORK \\
\hline \multirow[t]{5}{*}{ Ethnicity } & Akan (ref.) & 1.00 & & & & 1.00 & & & \\
\hline & Ga-Adangbe & 0.79 & $0.40 *$ & $3.59 *$ & 0.59 & $0.53^{* * *}$ & $0.54 * *$ & $2.54^{*}$ & 1.22 \\
\hline & Ewe & $0.63^{* * *}$ & 0.91 & I.89**** & 0.85 & $0.62 * * *$ & 1.09 & I. $44^{* * * *}$ & 0.81 \\
\hline & Mole-Dagbani & $3.0 I^{*}$ & $0.38^{*}$ & 0.76 & $0.52 * * *$ & 1.35 & 0.74 & 1.40 & $0.5 \mathrm{I} * * *$ \\
\hline & Others & $2.93^{*}$ & $0.35^{*}$ & $0.67 * * *$ & 1.32 & 1.33 & 0.73 & 0.97 & 1.06 \\
\hline \multirow[t]{4}{*}{ Religion } & Christian (ref.) & 1.00 & & & & 1.00 & & & \\
\hline & Islam & $0.65^{*}$ & 1.21 & I.70* & 0.71 & 0.97 & 0.97 & 1.18 & 0.96 \\
\hline & Traditional & 0.93 & 1.16 & 1.01 & $0.18^{*}$ & 1.16 & 0.98 & 1.31 & $\mathrm{~N} / \mathrm{A}$ \\
\hline & No religion,etc & 1.01 & 0.97 & 01.05 & 0.82 & 0.99 & 1.10 & 0.65 & 1.32 \\
\hline \multirow[t]{2}{*}{ Location } & Urban (ref.) & 1.00 & & & & 1.00 & & & \\
\hline & Rural & 3.96 & $1.33^{*}$ & $0.09 *$ & $0.10 *$ & $2.66^{*}$ & $2.22 *$ & $0.34 *$ & $0.27^{*}$ \\
\hline \multirow{3}{*}{$\begin{array}{l}\text { Dwelling } \\
\text { type }\end{array}$} & Self contained & $1.91 *$ & $0.25 *$ & 0.76 & $5.14 *$ & 1.28 & 0.79 & 0.94 & 1.16 \\
\hline & Compound (ref.) & 1.00 & & & & 1.00 & & & \\
\hline & Tents \& huts & $0.73^{*}$ & $1.24 * * *$ & I. $25 * * * *$ & 0.67 & 0.83 & $|.5|$ |*** & 0.87 & 0.47 \\
\hline \multirow[t]{2}{*}{ Use ICT } & Use (ref.) & 1.00 & & & & 1.00 & & & \\
\hline & Don't use & $2.96^{*}$ & 0.81 & $0.42 *$ & 1.09 & $3.13^{*}$ & 1.09 & $0.45 *$ & 1.11 \\
\hline \multirow[t]{4}{*}{ Age } & $21-25$ & 1.02 & $0.75 * * *$ & 1.20 & 1.62 & 1.01 & 0.85 & 1.23 & 0.90 \\
\hline & $26-30$ (ref.) & 1.00 & & & & 1.00 & & & \\
\hline & $31-35$ & 0.95 & 1.01 & 0.99 & 1.36 & 0.88 & 1.12 & 1.17 & 0.68 \\
\hline & $36-40$ & $0.68^{*}$ & 1.06 & $1.60 *$ & 0.95 & $0.6 I^{* *}$ & $1.66 * *$ & $1.00 *$ & 0.73 \\
\hline \multirow{2}{*}{$\begin{array}{l}\text { Marital } \\
\text { status }\end{array}$} & Married (ref.) & 1.00 & & & & 1.00 & & & \\
\hline & Not married & $2.35^{*}$ & $0.38^{*}$ & 1.08 & 1.06 & $2.66 *$ & $0.38^{*}$ & I.II & 0.97 \\
\hline \multirow[t]{2}{*}{ Sex } & Male & $0.32 *$ & $4.89 *$ & $0.26 *$ & $6.44 *$ & $0.38^{*}$ & $4.11 *$ & $0.18^{*}$ & $6.55^{*}$ \\
\hline & Female (ref.) & 1.00 & & & & 1.00 & & & \\
\hline \multicolumn{5}{|c|}{$\begin{array}{l}\text { N } 2570 \text { (No education and have done some work in past I } 2 \text { months); } \\
R C^{2} i^{2}(17)=534.72 ; \text { Prob }>\text { chi }^{2}=0.000 ; \text { Pseudo } R^{2}=0.15 ; \\
\text { Log Likelihood }=-1483.40\end{array}$} & \multicolumn{5}{|c|}{$\begin{array}{l}\text { N I I } 87 \text { (Primary and some work in past I } 2 \text { months); } \\
\text { R Chi }{ }^{2}\left(\text { I7) }=\text { I94.73; Prob }>\text { chi }^{2}=0.000 ; \text { Pseudo } R^{2}=0.15 ;\right. \\
\text { Log Likelihood = -525.35 }\end{array}$} \\
\hline
\end{tabular}

Source: GSS (2005/2006); Authors' Computation $* 10 \% \quad * * 5 \% \quad * * * 1 \%$ 
Table 4: Factors influencing employment security of persons from higher levels of education : Middle/JHS and SHS+

\begin{tabular}{|c|c|c|c|c|c|c|c|c|c|}
\hline \multirow{2}{*}{\multicolumn{2}{|c|}{ REGRESSORS }} & \multicolumn{4}{|l|}{ MIDDLE/JHS } & \multicolumn{4}{|l|}{ SHS+ } \\
\hline & & $\begin{array}{l}\text { SUBSISTENCE } \\
\text { AGRIC }\end{array}$ & $\begin{array}{l}\text { COMMERCIAL } \\
\text { AGRIC }\end{array}$ & $\begin{array}{l}\text { SELF } \\
\text { EMPLOYMENT }\end{array}$ & $\begin{array}{l}\text { PAID } \\
\text { WORK }\end{array}$ & $\begin{array}{l}\text { SUBSISTENCE } \\
\text { AGRIC }\end{array}$ & $\begin{array}{l}\text { COMMERCIAL } \\
\text { AGRIC }\end{array}$ & $\begin{array}{l}\text { SELF } \\
\text { EMPLOYMENT }\end{array}$ & PAID WORK \\
\hline Ethnicity & $\begin{array}{l}\text { Akan (ref.) } \\
\text { Ga-Adangbe } \\
\text { Ewe } \\
\text { Mole-Dagbani } \\
\text { Others }\end{array}$ & $\begin{array}{l}\mathrm{I} .00 \\
0.6 \mathrm{I} * * * \\
0.57 * \\
\mathrm{I} .57 * * \\
\mathrm{I} .72 * * *\end{array}$ & $\begin{array}{l}0.57^{* *} \\
1.39 * * \\
0.81 \\
0.62 * * *\end{array}$ & $\begin{array}{l}\mathrm{I} .58^{*} \\
\mathrm{I} .1 \mathrm{I} \\
\mathrm{I} .13 \\
\mathrm{I} .33\end{array}$ & $\begin{array}{l}1.17 \\
0.87 \\
0.66 * * * \\
0.59 * * *\end{array}$ & $\begin{array}{l}1.00 \\
\text { N/A } \\
1.39 \\
1.69 \\
1.65\end{array}$ & $\begin{array}{l}0.99 \\
1.33 \\
2.26 * * \\
0.91\end{array}$ & $\begin{array}{l}0.70 \\
1.08 \\
0.48^{*} \\
0.90\end{array}$ & $\begin{array}{l}1.67^{* * * *} \\
0.85 \\
1.08 \\
0.86\end{array}$ \\
\hline Religion & $\begin{array}{l}\text { Christian (ref.) } \\
\text { Islam } \\
\text { Traditional } \\
\text { No religion,etc }\end{array}$ & $\begin{array}{l}1.00 \\
0.95 \\
1.79 \\
1.35\end{array}$ & $\begin{array}{l}0.90 \\
0.36 * * \\
0.76\end{array}$ & $\begin{array}{l}1.03 \\
1.47 \\
0.99\end{array}$ & $\begin{array}{l}1.17 \\
0.91 \\
1.01\end{array}$ & $\begin{array}{l}1.00 \\
0.66 \\
2.4^{* *} \\
4.91^{* *}\end{array}$ & $\begin{array}{l}I .14 \\
N / A \\
N / A\end{array}$ & $\begin{array}{l}2.01 * * \\
5.65 \\
0.85\end{array}$ & $\begin{array}{l}0.5 I^{*} \\
\mathrm{~N} / \mathrm{A} \\
\mathrm{I} .24\end{array}$ \\
\hline Location & $\begin{array}{l}\text { Urban (ref.) } \\
\text { Rural }\end{array}$ & $\begin{array}{l}1.00 \\
3.01 *\end{array}$ & $9.67^{*}$ & $0.57^{*}$ & $0.47^{*}$ & $\begin{array}{l}1.00 \\
5.57 * *\end{array}$ & $2.88^{*}$ & $0.6 I^{*}$ & $0.69 *$ \\
\hline $\begin{array}{l}\text { Dwelling } \\
\text { type }\end{array}$ & $\begin{array}{l}\text { Self contained } \\
\text { Compound (ref.) } \\
\text { Tents \& huts }\end{array}$ & $\begin{array}{l}0.79 \\
1.00 \\
0.89\end{array}$ & $\begin{array}{l}0.58^{* *} \\
1.48^{* * * *}\end{array}$ & $\begin{array}{l}1.11 \\
0.85\end{array}$ & $\begin{array}{l}1.3 I^{*} \\
0.78\end{array}$ & $\begin{array}{l}0.289 * * \\
1.00 \\
0.87\end{array}$ & $\begin{array}{l}0.62 \\
1.08\end{array}$ & $\begin{array}{l}0.7 I^{* * * *} \\
0.85\end{array}$ & $\begin{array}{l}1.6 I^{*} \\
0.88\end{array}$ \\
\hline Use ICT & $\begin{array}{l}\text { Use (ref.) } \\
\text { Don't use }\end{array}$ & $\begin{array}{l}1.00 \\
1.70 *\end{array}$ & $1.87^{*}$ & $0.56 *$ & 0.85 & $\begin{array}{l}1.00 \\
4.18^{*}\end{array}$ & $2.64 *$ & $0.67^{* * *}$ & $0.58^{*}$ \\
\hline Age & $\begin{array}{l}21-25 \\
26-30 \text { (ref.) } \\
31-35 \\
36-40\end{array}$ & $\begin{array}{l}1.20 \\
1.00 \\
0.97 \\
0.91\end{array}$ & $\begin{array}{l}0.99 \\
1.52 * \\
2.20 *\end{array}$ & $\begin{array}{l}0.87 \\
0.69 * \\
0.64 *\end{array}$ & $\begin{array}{l}1.04 \\
1.09 \\
0.82\end{array}$ & $\begin{array}{l}5.41^{*} \\
1.00 \\
0.76 \\
1.30\end{array}$ & $\begin{array}{l}0.53 \\
1.30 \\
0.90\end{array}$ & $\begin{array}{l}1.22 \\
0.91 \\
0.86\end{array}$ & $\begin{array}{l}0.58 * \\
1.09 \\
1.09\end{array}$ \\
\hline $\begin{array}{l}\text { Marital } \\
\text { status }\end{array}$ & $\begin{array}{l}\text { Married (ref.) } \\
\text { Not married }\end{array}$ & $\begin{array}{l}1.00 \\
1.88^{*}\end{array}$ & $0.29 *$ & 1.18 & $1.32 * *$ & $\begin{array}{l}1.00 \\
0.93\end{array}$ & 0.59 & $0.5 I^{*}$ & $2.03 *$ \\
\hline Sex & $\begin{array}{l}\text { Male } \\
\text { Female (ref.) }\end{array}$ & $\begin{array}{l}0.38^{*} \\
1.00\end{array}$ & $4.33 *$ & $0.19 *$ & $7.03^{*}$ & $\begin{array}{l}0.58^{* * * *} \\
1.00\end{array}$ & $5.66 *$ & $0.53^{*}$ & $1.43 * *$ \\
\hline \multicolumn{5}{|c|}{ 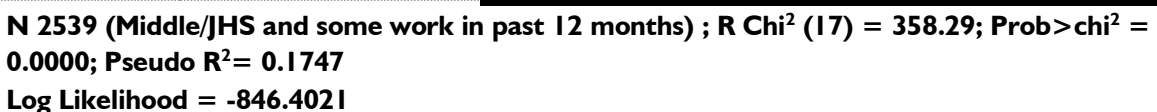 } & \multicolumn{5}{|c|}{$\begin{array}{l}\text { (N 939 (SHS+ and some work in past I2 months); LR Chi }{ }^{2}(I 5)=173.60 ; \text { Prob }>\text { chi }^{2}= \\
0.0000 ; \text { Pseudo } \mathrm{R}^{2}=0.31 \\
\text { Log Likelihood }=-189.079\end{array}$} \\
\hline
\end{tabular}

Source: GSS (2005/2006); Authors' Computation *10\% ***\% ***1\% 
Factors enhancing or mitigating high level of education endowments among women and rural dwellers (Table 5)

We have seen above that a high education level does not erase disadvantage in job opportunities of women and of rural dwellers. We focus here on these two subpopulations to consider what factors can enhance the effect of a higher education in opening to them those job opportunities that they are less able to access. In other words, what enable women with middle/high education to access activities globally more represented among men - i.e. commercial agric and paid jobs - and those living in rural areas to work in non-agric jobs.

\section{Unequal job access among more educated women}

The ethnic belonging is a major factor of differential access of educated women to job opportunities such as shown by the fact that differences are stronger than among highly educated people in general (results for both sex shown in Table 4). Compared to the Akan, Mole Dagbani women and those in other types of ethnicity are much more likely to work in subsistence agric and less on commercial basis, while Ga-Adangbe and Ewe women are more likely to be self-employed. Among highly educated women, ethnicity however does not play a role as regard access to a paid job.

Muslim highly educated women have a lower probability than Christian to work in the agric sector and, as was the case for both sexes, they are more likely to be self-employed but less likely to work in the agric sector. Among highly educated women, residence in a selfcontained dwelling is strongly associated with access to paid jobs. Those using ICT are more likely to engage in well-paid and secured types of work (commercial agric and paid work).

Among highly educated women, age only discriminates those above 35 years, who are less likely to work in subsistence agric and more in commercial and non-agric self-employment. This may be because, at that age, they are mothers and wifes and must therefore engage in better paid jobs to support the family, what is also consistent with the much higher access to commercial agric among married women. However, age and marital status have no effect on access to paid jobs.

In short, inequalities of female access to masculine sphere of activities are not erased by higher education. Among highly educated women, commercial agric is less accessible when belonging to ethnic groups different from Akan and Ewe and among Muslim (but this is the case for activities in agric in general); access is enhanced when above 35 years and married. Paid job is also still less accessible among MoleDagbani, among groups of traditional religion and of women living in poorer dwellings.

Unequal job access among more educated rural dwellers

Ethnicity is a factor of differential job access among higher educated rural, but with effects different from those among the highest educated in general (called general more educated population hereafter). With Akans as the reference category, Ga-Adangbe are more likely to be self-employed and Ewe to work in commercial agric but both less likely to work in subsistence agriculture. When living in rural area, a higher education may lead Ewe rural people to commercialize instead of subsistence agric, and the Ga-Adangbe to orient themselves towards non agric self-employment rather than paid work such as in the general more educated population. Rural people with higher education who practice Islam and other religion are not likely to be self-employed. However, those in other religious groups have a higher probability of working in paid jobs. Those who live in selfcontained houses are 2.47 times likely to work in paid jobs and less in any form of agriculture. Rural people who have attained Middle+ level of education and live in tents and huts are 1.48 times likely to commercial agric than those in compound dwellings. Effects of ICT use, age and marital status don't differ from the general more educated population. 
In short, it is not surprising to see rural people work in any form of agric even if they have a higher education, perhaps it is the only type of work available in the rural areas. They have a higher probability to access work opportunities out of the agriculture sector when they belong to the Ga-Adangbe and when they have no religion and live in a self-contained dwelling. 
Table 5: Factors influencing employment security of women and of rural dwellers with higher education (Middle+)

\begin{tabular}{|c|c|c|c|c|c|c|c|c|c|}
\hline \multirow{2}{*}{\multicolumn{2}{|c|}{ REGRESSORS }} & \multicolumn{4}{|c|}{ WOMEN WITH MIDDLE+ } & \multicolumn{4}{|c|}{ RURAL PEOPLE WTHH MIDDLE+ } \\
\hline & & $\begin{array}{l}\text { SUBSISTENCE } \\
\text { AGRIC }\end{array}$ & $\begin{array}{l}\text { COMMERCIAL } \\
\text { AGRIC }\end{array}$ & $\begin{array}{l}\text { SELF } \\
\text { EMPLOYMENT }\end{array}$ & $\begin{array}{l}\text { PAID } \\
\text { WORK }\end{array}$ & $\begin{array}{l}\text { SUBSISTENCE } \\
\text { AGRIC }\end{array}$ & $\begin{array}{l}\text { COMMERCIAL } \\
\text { AGRIC }\end{array}$ & $\begin{array}{l}\text { SELF } \\
\text { EMPLOYMENT }\end{array}$ & PAID WORK \\
\hline Ethnicity & $\begin{array}{l}\text { Akan (ref.) } \\
\text { Ga-Adangbe } \\
\text { Ewe } \\
\text { Mole-Dagbani } \\
\text { Others }\end{array}$ & $\begin{array}{l}1.00 \\
0.56^{* *} \\
0.67^{* *} \\
2.68^{*} \\
2.10^{*}\end{array}$ & $\begin{array}{l}0.37^{*} \\
1.06 \\
0.48^{*} \\
0.55^{*}\end{array}$ & $\begin{array}{l}3.57 * \\
1.48 * * \\
0.68 * * \\
0.69 * *\end{array}$ & $\begin{array}{l}1.02 \\
0.65 \\
0.40 * \\
0.80\end{array}$ & $\begin{array}{l}1.00 \\
0.49 * * \\
0.56 * \\
1.10 \\
1.05\end{array}$ & $\begin{array}{l}0.81 \\
1.43^{*} * \\
1.08 \\
0.66\end{array}$ & $\begin{array}{l}1.55^{* *} \\
0.99 \\
0.77 \\
0.84\end{array}$ & $\begin{array}{l}1.38 \\
1.07 \\
1.11 \\
1.27\end{array}$ \\
\hline Religion & $\begin{array}{l}\text { Christian (ref.) } \\
\text { Islam } \\
\text { Traditional } \\
\text { No religion,etc }\end{array}$ & $\begin{array}{l}1.00 \\
0.79 * * * * \\
1.00 \\
1.23\end{array}$ & $\begin{array}{l}0.76 * * * \\
1.73 * \\
1.10\end{array}$ & $\begin{array}{l}1.64 * \\
0.57^{* *} \\
0.77\end{array}$ & $\begin{array}{l}0.84 \\
0.13^{*} \\
1.06\end{array}$ & $\begin{array}{l}1.00 \\
1.05 \\
1.75 \\
0.97\end{array}$ & $\begin{array}{l}1.12 \\
0.58 \\
1.09\end{array}$ & $\begin{array}{l}0.66 * * * \\
1.61 \\
0.64 * * *\end{array}$ & $\begin{array}{l}1.23 \\
0.24 \\
1.57 * * *\end{array}$ \\
\hline $\begin{array}{l}\text { Dwelling } \\
\text { type }\end{array}$ & $\begin{array}{l}\text { Self contained } \\
\text { Compound (ref.) } \\
\text { Tents \& huts }\end{array}$ & $\begin{array}{l}1.23 \\
1.00 \\
0.95\end{array}$ & $\begin{array}{l}0.41^{*} \\
1.02\end{array}$ & $\begin{array}{l}0.80 \\
1.09\end{array}$ & $\begin{array}{l}2.03 * * \\
0.59 * * *\end{array}$ & $\begin{array}{l}0.59 * * \\
1.00 \\
0.83\end{array}$ & $\begin{array}{l}0.55 * * \\
1.48 * *\end{array}$ & $\begin{array}{l}1.12 \\
0.94\end{array}$ & $\begin{array}{l}2.47^{*} \\
0.67\end{array}$ \\
\hline Use ICT & $\begin{array}{l}\text { Use (ref.) } \\
\text { Don't use }\end{array}$ & $\begin{array}{l}1.00 \\
4.75^{*}\end{array}$ & $1.32 * *$ & $0.25^{*}$ & $0.43^{*}$ & $\begin{array}{l}1.00 \\
1.67^{*}\end{array}$ & $1.95 *$ & $0.54 *$ & $0.5 I^{*}$ \\
\hline Age & $\begin{array}{l}21-25 \\
26-30 \text { (ref.) } \\
31-35 \\
36-40\end{array}$ & $\begin{array}{l}0.87 \\
1.00 \\
0.82 \\
0.59 *\end{array}$ & $\begin{array}{l}1.02 \\
1.14 \\
1.2 * * *\end{array}$ & $\begin{array}{l}1.14 \\
1.08 \\
1.41^{* *}\end{array}$ & $\begin{array}{l}0.99 \\
1.19 \\
0.93\end{array}$ & $\begin{array}{l}1.63^{* *} \\
1.00 \\
0.91 \\
0.85\end{array}$ & $\begin{array}{l}0.70 * * \\
1.32 * * * \\
1.93 *\end{array}$ & $\begin{array}{l}1.07 \\
\\
0.83 \\
0.52 *\end{array}$ & $\begin{array}{l}0.77 \\
0.89 \\
0.86\end{array}$ \\
\hline $\begin{array}{l}\text { Marital } \\
\text { status }\end{array}$ & $\begin{array}{l}\text { Married (ref.) } \\
\text { Not married }\end{array}$ & $\begin{array}{l}1.00 \\
1.05\end{array}$ & $0.50^{* *}$ & 1.08 & 1.07 & $\begin{array}{l}1.00 \\
1.14\end{array}$ & $0.45^{*}$ & 0.88 & $2.56 *$ \\
\hline \multicolumn{5}{|c|}{$\begin{array}{l}\text { Number of observations }(\mathrm{N}): 2418 \text {; LR Chi }{ }^{2}(14)=348.02 ;{\text { Prob }>\text { chi }^{2}=0.0000 ;} \text { Pseudo } R^{2}= \\
0.106 \mid \\
\text { Log Likelihood = - } 1466.0538\end{array}$} & \multicolumn{5}{|c|}{$\begin{array}{l}\text { Number of observations }(\mathrm{N}) \text { : } 1667 ; \operatorname{LR~Chi~}^{2}(14)=105.23 ; \quad \text { Prob }>\text { chi' }^{2}=0.0000 \\
\text { Pseudo } R^{2}=0.0717 \\
\text { Log Likelihood }=-680.7795 \mathrm{I}\end{array}$} \\
\hline
\end{tabular}




\section{Conclusion and policy \\ recommendations}

Recall that the aim of this study is to reconsider the role of education endowments in inequalities in job opportunities by analyzing differences between and within educational endowments. Between endowments differences confirm that the highest educational qualifications offer higher opportunities for stable and higher income jobs (i.e. paid work) and vice versa. However, job types do not exactly match with endowments groups. Only about half of those with the highest endowments have paid jobs and, among men, paid work is also over represented among those with middle-high schooling. Commercial agric includes nearly as many individuals with no education than with primary education, while self-employment is to be found among those with primary and middle education attainments. Education is a condition to access to some types of work, but there are also other constraints to these job opportunities. These constraints include social capital (social networking), discrimination, success in job interviews, aptitude test and experience. There may be some personal preferences for a particular type of work no matter the individual's educational qualification.

There is a strong association between education levels and job achievements among those sectors of the population in which the distribution of the four types of professional activities match the ranking adopted here in one direction or the other. The proportion of Akan, Christian, urban dwellers and ICT users, in other words of people more in contact with modern ideas and technologies, increases across employment from subsistence agric to commercial agric, non agric self-employed and paid work, while the opposite is true for MoleDagbani, rural dwellers, those declaring traditional religions and living in huts or tents. The same gradient is not found among other ethnic groups, Muslims, other types of dwellings, age groups and marital status and, most of all, gender. The results show that they have differential access to different types of activities and that education is not erasing these specificities.

The analysis of the differentials in job opportunities within endowments, i.e. among individuals with the same level of education, shows that education does not erase inequalities and that, to a certain degree, lack or poor education does not affect everybody equally. This is especially the case as regards gender inequalities and rural/urban ones. For instance, at any level of education, males have greater job opportunities in commercial agric and in paid work than females. Higher schooling does not erase gender inequalities, especially access to paid jobs, but neither inequalities among women. Significative differences in job opportunities remain among women with middle or high schooling for all characteristics considered here: as much cultural norms and lifestyles such as expressed by ethnic and religious belonging, as household characteristics and position in the lifecourse. Worth noting also is the better access of women over 35 years and married to commercial agric.

Non agric self-employed activities appear to offer opportunities to those generally discriminated in higher level jobs, i.e. women and, to a lesser extent, rural dwellers. It may be seen as the consequence of obstacles to access to paid jobs among those with higher levels of education, but also as informal options at lower levels, especially for women. In fact, men with no or primary education are mostly found in the agriculture sector while one quarter of women without education, and a little less than half of those with primary, are engaged in non agric self-employed activities.

Position in the life course highlights the role of age and marital status in gaining more experience, family responsibilities and a higher status on job achievement such as shown by an increased involvement of older and married people in commercial agric at all levels of education except SHS+. This is also shown by the fact that people aged $21-25$ dominate in 
higher education, but among the most educated, they are more likely to work on subsistence farming.

The family composition such as expressed by the relative valorization of education endowment among people living in selfcontained dwellings compared to those in compound dwellings highlights the complex meanings of the nuclear family. People living in self-contained dwellings, i.e. nuclear family, clearly have a higher education level and are more often working in paid jobs when they have a middle or high education level. This is especially the case among higher educated women and rural dwellers. However, among those with no education active in the agriculture sector, they are more often in subsistence agriculture while those living with larger households in compound dwellings are more active in commercial agric. This may point to the importance of family ties for these types of activities.

In short, our results show that education endowment is better valorized among those people who belong to more modern sectors of the population, which means that education is also carrying increasing inequalities. Moreover, these gaps are reinforced by inequalities due to the cultural context, gender and age.

It will be worth studying in deeper details these findings. In particular, one major limitation of the study is the inability to use the GLSS5 data to estimate the individuals' preferences. It should also be useful to consider more detailed job categories and include multiple activities. Moreover, the data is nine years old and may not reflect current situations.

Based on these results, it should be recommended to enhance universal access to education, but also the ability to use it and develop specific skills and job opportunities:

Since stable and high-income jobs require higher educational qualifications, there is the need to encourage individuals to pursue education to the highest level. The necessary steps to increase the gender parity index in our schools should be encouraged. Policies aimed at reducing inequalities in education should be targeted at location. This calls for the development of educational infrastructure at the rural areas of Ghana. Some cultural and religious practices, which serve as impediments to educational enrolment, should be discarded in Ghana.

However, specific skills should also be enhanced, especially individuals' access to and use of ICT - mobile phone, personal computer, fixed line telephone and internet. A friendly environment should be created for the proliferation of social networking. Individuals must be empowered to ensure success in interviews and aptitude tests.

It is not enough to provide citizens with education and skills; job opportunities must be available and to the reach of all individuals without discrimination. Provision of paid jobs in other locations apart from Greater Accra Metropolitan Area is essential for reducing inequalities in access to paid work. Any public policy aimed at encouraging individuals to set up their own businesses (selfemployment) should be targeted at those with lower levels of education.

Special attention should be given to the persistence of unequal access of women to job opportunities and better understand the remaining obstacles in terms of cultural norms and lack of empowerment that explain their lower access to commercial agriculture and paid work.

\section{Bibliography}

Ghana Statistical Service (2005/2006), 'Ghana Living Standard Survey (5), Accra, Ghana.

Greene, William H. (2003), Econometric Analysis, fifth edition, Prentice Hall.

Kingdon, Geeta and Måns Söderbom (2007). Education, Skills, and Labour Market 
Outcomes: Evidence from Ghana. Paper available at (accessed I5/05/II): http://recoup.educ.cam.ac.uk/publications/G eetaGhanaPaper98-99.pdf..

Lavy, V. (1992). Investment in Human Capital: Schooling Supply Constraints in Rural Ghana'. LSMS Working Paper 93. Washington, DC: The World Bank.

Mancini, Luca (2009). Comparative Trends in Ethno-Regional Inequalities in Ghana and Nigeria: Evidence from Demographic and Health Surveys. Centre for Research on Inequality, Human Security and Ethnicity (CRISE) Working Paper No. 72.

Sackey, Harry A. (2005). Female Labour Force Participation in Ghana: The Effects of Education. African Economic Research Consortium (AERC) Research Paper No. 150, Nairobi.

Sen, A. (1999), Development as Freedom. New York: Knopf Press.
Sunal, C.S., D.W. Sunal, R. Rufai, A. Inuwa and M.E. Haas (2003). Perceptions of Unequal Access to Primary and Secondary Education: Findings from Nigeria. African Studies Review 46.1: $93-116$

Teal, Francis (200I). Education, Incomes, Poverty and Inequality in Ghana in the 1990s. CSAE WPS/200I-2I.

Uwaifo Oyelere, R. (2005). Africa's Education Enigma: The Nigerian Story. Paper presented at the American Agricultural Economics Association Annual Meeting, Long Beach, California, 23-26 July 2006). Mimeo, UC Berkeley.

' Parents' education was introduced as a family variable, but many were missing or insignificant. Therefore, it has been dropped from the model. 